\title{
Ecological relations between mangrove leaf litter and the spatial distribution of the gastropod Melampus coffeus in a fringe mangrove forest
}

\author{
Diva S. Tavares' ${ }^{1}$ Rafaela C. Maia², Cristina Rocha-Barreira³ \& Helena Matthews-Cascon
}

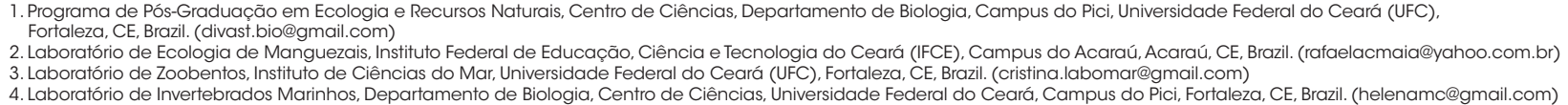

\begin{abstract}
Leaf litter represents a food source to many organisms that may directly contribute to organic matter decomposition. In addition, the physical presence of these vegetal detritus contributes for the modification of some environmental areas and produce microhabitats that may act as a refuge against predators and desiccation for many animals. The pulmonate gastropod Melampus coffeus (Linnaeus, 1758) (Ellobiidae) is a very common specie in Atlantic Coast mangrove forests and feeds on fallen mangrove leaves. It was hypothesized that the spatial distribution of Melampus coffeus is directly affected by mangrove leaf litter biomass deposition. Thus, this research aimed at evaluating the spatial distribution of these gastropods in relation to the biomass of mangrove leaf litter through a twelve-month period. The study area was established in the middle estuary of Pacoti River, state of Ceará, Brazil where two adjacent zones with different topographic profiles were determined. Samples of Melampus coffeus and leaf litter were collected monthly, throughout a year, from the mangrove ground surface. The results indicated that the presence of twigs in mangrove litter favor the occupation by smaller individuals of $M$. coffeus, probably because smaller individuals are more susceptible to predator attacks and desiccation than larger ones, and twigs and branches may provide a safe microhabitat.
\end{abstract}

KEYWORDS. Ellobiidae, macrodetritivore, microhabitat, Pacoti river, Rhizophora mangle.

RESUMO. Relações ecológicas entre a serrapilheira de manguezal e a distribuição espacial do gastrópodo Melampus coffeus em uma borda de floresta de mangue. A serapilheira representa fonte de alimentos para diversos organismos que podem contribuir diretamente para a decomposição de matéria orgânica. A presença física desses detritos vegetais pode modificar áreas do ambiente e promover a formação de microhabitats, servindo de refúgio para diversos animais contra predadores e dessecação. O gastrópode Melampus coffeus (Linnaeus, 1758) (Ellobiidae) é comum em florestas de mangue na costa do Atlântico e se alimenta de folhas de mangue caídas. Nesse trabalho foi assumida a hipótese de que a distribuição espacial do Melampus coffeus é diretamente afetada pela deposição de serapilheira no manguezal. Objetivou-se avaliar a distribuição espacial desses gastrópodes em relação à serapilheira de mangue durante doze meses de coletas. A área de estudo foi estabelecida no médio estuário do rio Pacoti, Estado do Ceará, Brasil onde foram determinadas duas zonas de diferentes perfis topográficos. Amostras de Melampus coffeus e de serapilheira foram coletadas mensalmente. Os resultados indicaram que a presença de galhos na superfície do solo do manguezal favorece a ocupação do ambiente por indivíduos dessa espécie de molusco de menor tamanho, provavelmente porque indivíduos menores são mais suscetíveis ao ataque de predadores e à dessecação e a presença de galhos pode formar microhabitats mais seguros.

PALAVRAS-CHAVE. Ellobiidae, macrodetritívoro, microhabitat, Rio Pacoti, Rhizophora mangle.

Mangrove forests harbor a large number of organisms of aquatic, terrestrial and intermediate habits (Odum \& Heald, 1972) and provide the resident and visitant fauna with food and shelter from predators (ODuM \& Heald, 1972; Camilleri, 1992; McIvor \& SMith, 1995; Acosta \& Butler, 1997). However, the availability of such resources depends on the structure and composition of mangrove forest, structural disposition of rhizophores and pneumatophores, leaf litter production and deposition, sedimentological features, besides other natural factors (Primaveira, 1997; Chapman et al., 2005; Kon et al., 2009). Thus, these variables may influence the abundance and diversity of the mangrove fauna, especially macro invertebrates.

According to Crowe (1996), physical and biological environmental factors may promote the formation of different microhabitats that often structure different patterns of spatial distribution of many organisms. Several researches have been carried out in mangroves of different regions of the world to show such relations. RöNNBÄCK et al. (2002), for example, studied the distribution of two shrimp species between different microhabitats, in a mangrove forest in eastern Africa. The researchers observed that Penaeus indicus (Milne Edwards, 1837) prefers sheltering in vegetated areas, especially the ones with muddy substrate, probably because these areas provide protection against predators. On the other hand, the shrimp species Metapenaeus monoceros (Fabricius, 1798) seems to search for sandy flat areas, where they bury themselves in the sand, likely as a strategy for protection from predators.

Other animals that inhabit mangrove areas also have shown the need for microhabitats. Crabs compose the typical fauna of mangrove areas and they are known as bio constructor animals, as these invertebrates have the ability to construct their own burrow in mangrove substrate to obtain protection against predators and desiccation by sheltering in their own burrow or in burrow of others (WARNER, 1969). 
Even though many studies have evidenced the importance of microhabitats as shelters against predators, Kon et al. (2009) did not find such significance in Thailand red mangroves. However, they observed more abundance of species in vegetated microhabitats. In addition, microhabitats also provide many mangrove animals, such as molluscs, crustaceans (Odum \& Heald, 1972) and polychaeta (Skilleter \& WARren, 2000), with food resources.

CHAPMAN et al. (2005) tested the influence of litter and algae amounts and pneumatophore length in the demographic density of the snails Ophicardelus spp. and Salinator solida (Martens, 1878). They manipulated these environmental features and verified that even though these pulmonate snails do not eat fresh mangrove leaves, they can feed upon small plant detritus, fungi and microalgae, which may explain the decreased population density of both species in areas with reduced litter. Other example is the gastropod Ovassiminea brevicula (Pfeiffer, 1854) that prefers to inhabit areas where the substrate of the forest is covered with a dense layer of leaves, twigs and seedlings (SUzuki et al., 2002).

The gastropod Melampus coffeus (Pulmonata, Ellobiidae) is a very common snail in mangrove forests and salt marshes along the Atlantic Ocean coast (Rios, 1994) and has a particular behavior related to tidal cycles, sheltering during spring tide. Adult individuals (shell height $>4 \mathrm{~mm}$ ) often climb trunks, seedlings, prop roots and pneumatophores to avoid submergence during flooding time, while juveniles (shell height $<4 \mathrm{~mm}$ ) remain on substrate surface under leaves and inside trunks (ProfFitT \& Delvin, 2005).

Because of the dynamic and daily behavior of this species, the structure of the mangrove forest may represent a fundamental factor for the survivor of these animals. MAIA \& TANAKA (2007) evaluated the effects of mangrove structure on the spatial distribution of Melampus coffeus. They observed, for example, that the largest snails were found on Rhizophora mangle during flooding, while the smallest ones were found on Laguncularia racemosa. According to the authors, these findings may be explained by the fact that the short stature and the diameter at breast height of $L$. racemosa trees are not enough to supply resources to support largest snails.

Although little is known about the biology and ecology of Melampus coffeus, some studies reported that these gastropods feed on mangrove leaves on the substrate surface, during low tide (Мook, 1986; ProffitT et al., 1993; TAVARes et al., 2011). For this reason, $M$. coffeus is considered a very important agent for leaf litter decomposition in mangrove forests and acts as a link between mangrove forests and estuarine food webs (Proffitt \& Delvin, 2005). Apart from the fact that leaf litter provides these animals with food resource, the physical presence of these vegetal detritus may increase the humidity retention on the ground, creating a particular environment that prevents desiccation. These features creates a favorable microhabitat for snails with smaller shell length, as observed by TAVAREs et al. (2011) in a mangrove in Northeastern Brazil.

Based on these researches, the hypothesis that higher population densities of Melampus coffeus, as well as the smaller ones, are found in areas with a greater amount of leaf litter biomass was proposed. Thus, the present study aimed at evaluating the spatial distribution of M. coffeus in relation to different leaf litter fractions and total leaf litter biomass in a fringe mangrove of the middle estuary of Pacoti River, Ceará, Northeastern Brazil.

\section{MATERIAL AND METHODS}

Study area. The estuary of Pacoti River is approximately $15-\mathrm{km}$-long and has about 160 ha of mangrove forest (GoRAYEB et al., 2005). The mangrove area of Pacoti River belongs to the "Área de Proteção Ambiental de Pacoti" (APA Pacoti), which has an area of 2,914.95 ha and is located $30 \mathrm{~km}$ from the city of Fortaleza, state of Ceará (SEmACE, 2009). The present work was carried out in the middle estuary of Pacoti River, which corresponds to a transition area, presenting intermediate features between sea water and fresh water with salinity of $0.05 \% \mathrm{o}$.

The experimental area was installed at the "Centro de Estudos em Aquicultura Costeira" (CEAC) of the "Instituto de Ciências do Mar", Eusébio, in the left side of Pacoti river $\left(03^{\circ} 49^{\prime} 59,2^{\prime \prime} \mathrm{S} ; 38^{\circ} 25^{\prime} 13,0^{\prime \prime} \mathrm{W}\right)$. The region has a tropical hot sub-humid weather with mean temperature of 26 to $28^{\circ} \mathrm{C}$ and the rainy period goes from January to May (mean annual rainfall $1,379.9 \mathrm{~mm}$ ) and the subsequent months are usually dry (FUNCEME, 2010). The main mangrove species that occur in the area are Rhizophora mangle, Laguncularia racemosa, Conocarpus erecta and Avicennia sp.

Experimental design. The experimental site was established in a fringe mangrove dominated by Rhizophora mangle trees. However, this area is not continuous and showed a non-vegetated area (approximately $15 \mathrm{~m}^{2}$ ). Field observations allowed distinguishing two different sites, separated by this clearing area. So, these sites were designated as zone A and zone B. Each one had about $45 \mathrm{~m}$ extension and were divided in three plots with approximately $25 \mathrm{~m}^{2}$ each (SCHAEFFER-Novelli \& CinTRÓN, 1986), at least $15 \mathrm{~m}$ apart from each other.

Topographic profile. The topographic profile of each zone was estimated by the "communicating vessels" method, which is based on Stevin's Law. The values obtained with this method were recorded and entered in a spreadsheet so that a comparative topographic profile between the two zones could be obtained through a line graph (ANDRADE \& FERREIRA, 2006).

Abiotic factors. Some physical aspects were monthly measured in triplicate. The data were recorded to characterize environmental conditions at the moment of collection. Sediment, air and river water surface temperatures were taken with an infrared laser thermometer (DT8280. 
$0.1^{\circ} \mathrm{C}$ precision). River water salinity was measured with a common optical refractometer. The pluviometric data were obtained from the "Fundação Cearense de Meteorologia e Recursos Hídricos" (FUNCEME).

Litter deposition. Litter standing crop was randomly collected from floor at both zones, monthly, from January 2010 to December 2010, in thirty (fifteen from each zone) replicates from $25 \mathrm{~cm}$ x $25 \mathrm{~cm}$ quadrants. Samples were taken to the "Laboratório de Zoobentos do Instituto de Ciências do Mar", where they were softly cleaned to remove exceeding mud and separated in the following fractions: leaves, twigs, reproductive parts and miscellaneous. After this procedure the wet biomass of each sample was determined with analytical digital scale $(0.0001 \mathrm{~g}$ precision). Then, samples were oven-dried, at $60^{\circ} \mathrm{C}$, to constant biomass. In addition, the number of leaves was also recorded.

The spatial distribution of Melampus coffeus. The same collection method used for litter standing crop was applied to estimate the population density and shell length of Melampus coffeus, also by monthly sampling over a year. All these measures were taken in the field and he animals were returned to the environment. For shell length measures, a digital caliper was used $(0.01 \mathrm{~mm}$ precision $)$.

Statistical analysis. Topographic profiles from zones A and B were compared by a simple line graph. Leaf litter and $M$. coffeus data were analyzed for normality and homogeneity of variances and transformed when necessary. When datum transformation did not allow the performance of parametric tests, original data were taken for analysis.

To compare leaf litter biomass and Melampus coffeus variation throughout the sampled months between zone A and zone B, a multifactorial Analysis of Variance (ANOVA) $(\mathrm{P}<0.05)$ was applied for all data. The $\mathrm{F}$ test of ANOVA is robust enough and recommended, even when the assumptions for parametric tests are not reached (FeIR \& TOOTHAKER, 1974). To verify possible differences detected through ANOVA, Tukey's multiple comparison analysis was used.

To evaluate the relations between the total and fractionated leaf litter biomass and the spatial distribution of Melampus coffeus, the Spearman correlation test was applied with a $5 \%$ significance level.

All the statistical analysis was carried out in the Statistical 7.0 software (StAT SofT INC., 2004). Interpretation of correlation data was based on the value table proposed by SHIMAKURA (2006).

\section{RESULTS}

Topographical profile. Different topographic profiles were found for zones A and B. The first one showed a higher declivity, when compared to zone B (Fig. 1).

Abiotic factors. The major rainfall (over $100 \mathrm{~mm} /$ month) in 2010 year occurred during March, April and May. In January, February, June, July, November and December rainfall was very low (1-74 $\mathrm{mm} /$ month). In

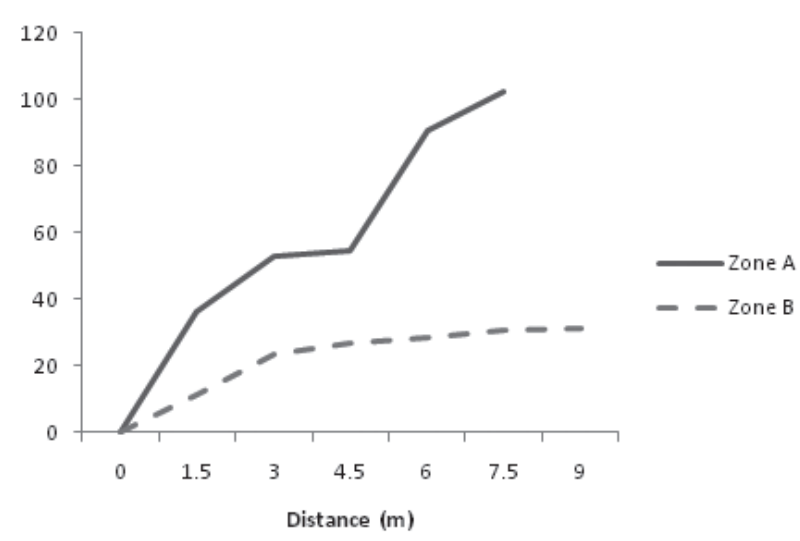

Fig. 1. Topographic profiles of zones A and B, "Área de Proteção Ambiental do Rio Pacoti”, Ceará, Brazil.

August, September and October, no rainfall was registered in the studied region (FUNCEME, 2010). In 2010, the total rainfall was approximately $40 \%$ lower than the mean annual rainfall known for the region (1379.9 $\mathrm{mm} /$ year).

Salinity of the river was reverse to rainfall and was $14 \% \mathrm{o}$ in April, when the largest rainfall happened. During the period when there was no rainfall, river water salinity reached $38 \%$ o, similar to sea water. The surface water, air, and sediment temperature ranges were, respectively, $28.1-30.8^{\circ} \mathrm{C}, 27.6-29.9^{\circ} \mathrm{C}$ and $27.9^{\circ} \mathrm{C}-30.6^{\circ} \mathrm{C}$.

Litter standing crop. Twigs were the most representative fraction in almost all analyzed months (Fig. 2) and showed a very strong correlation with the
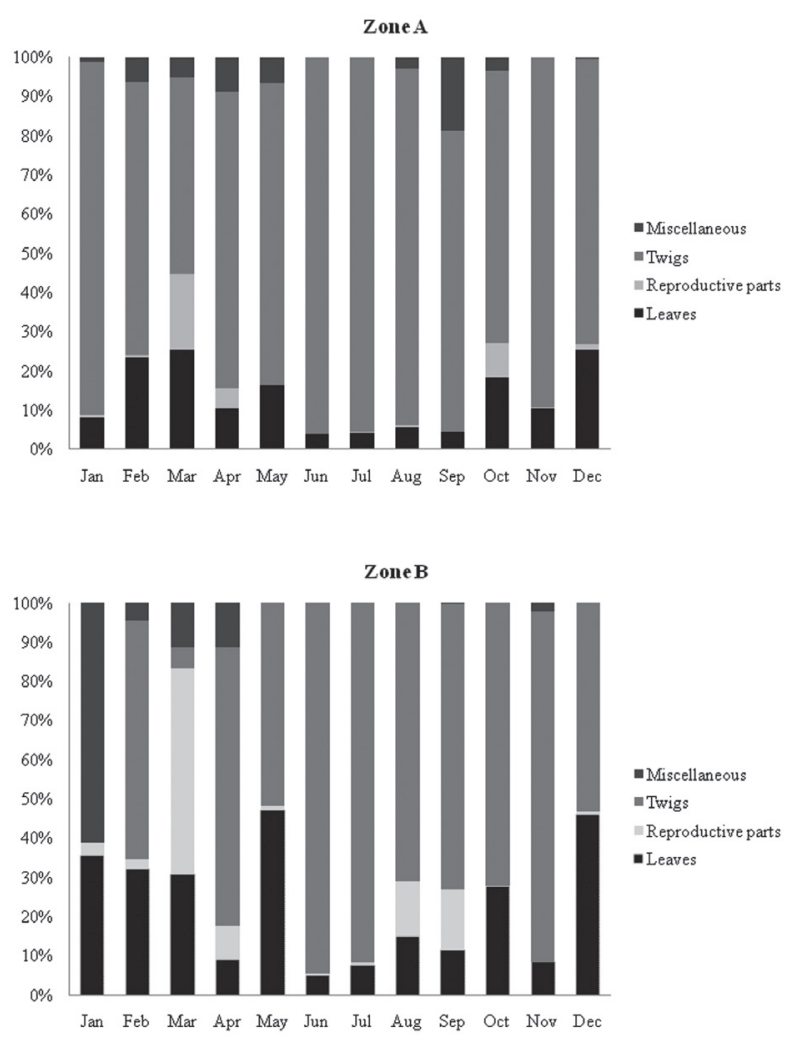

Fig. 2. Leaf litter fractions (\% of biomass) from zone A and B, "Área de Proteção Ambiental do Rio Pacoti”, Ceará, Brazil. 
Tab. I. Spearman's correlation result between wet and dry biomasses (W. B. and D. B., respectively) of different leaflitter fractions, “Área de Proteção Ambiental do Rio Pacoti”, Ceará, Brazil. Values in bold represents significance correlation $(\mathrm{p}<0.05)$.

\begin{tabular}{|c|c|c|c|c|c|}
\hline $\begin{array}{ll} & \text { D. B. } \\
\text { W. B. }\end{array}$ & Leaves & Reproductive parts & Twigs & Miscelaneous & Total \\
\hline Leaves & 0.942 & 0.116 & 0.083 & 0.156 & 0.373 \\
\hline Reproductive parts & 0.116 & 0.999 & 0.028 & 0.029 & 0.153 \\
\hline Twigs & 0.094 & 0.025 & 0.995 & 0.092 & 0.828 \\
\hline Miscelaneous & 0.137 & 0.038 & 0.069 & 0.973 & 0.242 \\
\hline Total & 0.385 & 0.146 & 0.804 & 0.274 & 0.977 \\
\hline
\end{tabular}

total biomass of leaf litter (Tab. I). Bifactorial analysis of variance did not detect significant differences comparing total leaf litter biomasses obtained in zones $\mathrm{A}$ and $\mathrm{B}$ throughout the year $\left(\mathrm{F}_{11,336}=1.668 ; \mathrm{P}=0.079\right)$ (Fig. 3). Anyway, the Tukey test was run and evidenced differences between zones A and B during January, June, July and August, when a bigger amount of twigs was found in zone A $\left(\mathrm{F}_{11,168}=1.972 ; \mathrm{p}=0.03\right)$ (Fig. 4). In zone B, however, there was no significant difference between the sampled months $\left(\mathrm{F}_{11,168}=1.680 ; \mathrm{p}=0.08\right)$.

Miscellaneous $\left(\mathrm{F}_{11.336}=0.428 ; \mathrm{P}=0.942\right)$, reproductive parts $\left(\mathrm{F}_{11,336}=0.354 ; \mathrm{P}=0.097\right)$ and leaves $\left(\mathrm{F}_{11,336}=0.258\right.$; $\mathrm{P}=0.992$ ) did not differ between zones throughout the studied period. The number of leaves was also similar in both zones $\left(\mathrm{F}_{11,336}=0.355 ; \mathrm{P}=0.971\right)$.

Spatial distribution of Melampus coffeus. In this research 1,375 individuals of Melampus coffeus were sampled and the lowest population density was recorded in zone A (3.2 individuals $\left./ \mathrm{m}^{2}\right)$, while the highest density was recorded in zone B (132.16 individuals $\left./ \mathrm{m}^{2}\right)$. The general means were 29.08 individuals $/ \mathrm{m}^{2}( \pm 12.97)$ in zone A and 88.21 individuals $/ \mathrm{m}^{2}( \pm 24.37)$ in zone B. Even though the population density of these snails were always highest in zone B (Fig. 5), the ANOVA test did not showed such difference $\left(\mathrm{F}_{11,336}=0.915 ; \mathrm{P}=0.525\right)$.

The smallest snail was recorded in zone A with 1.58 $\mathrm{mm}$ in length and the largest one had $21.3 \mathrm{~mm}$ length in the zone B. Analysis of variance turned evident that the smaller snails were always found in zone $\mathrm{A}$, while the larger ones were found in zone $\mathrm{B}\left(\mathrm{F}_{11,1351}=8.5102 ; \mathrm{P}=0.000\right)$ (Fig. 6).

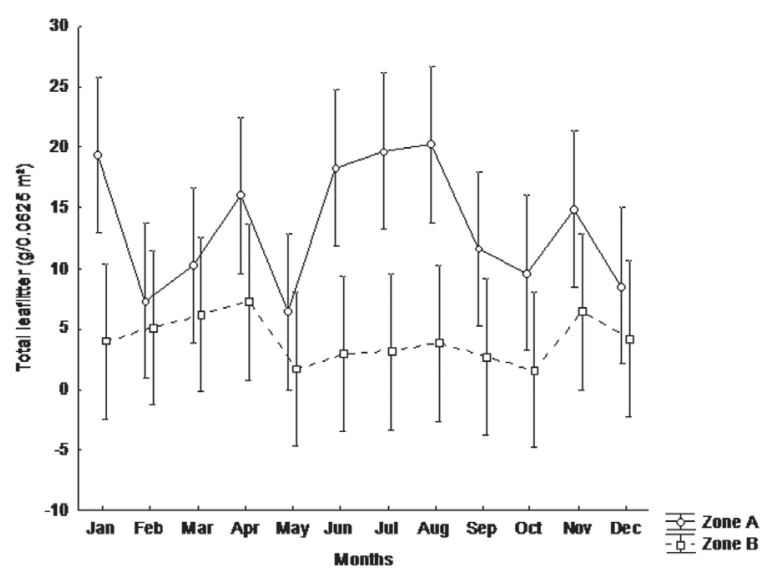

Fig. 3. Analysis of Variance $(p<0.05)$ between total leaflitter biomass from zone A and zone B during the period studied, "Área de Proteção Ambiental do Rio Pacoti”, Ceará, Brazil.

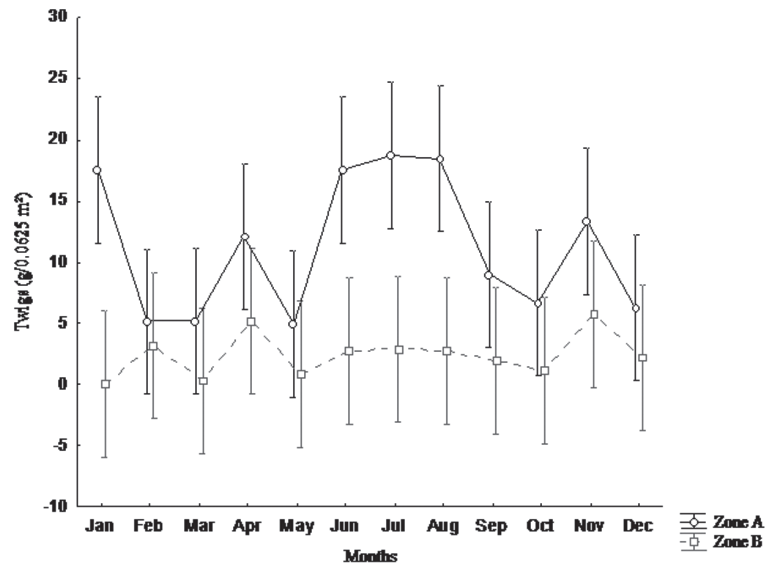

Fig. 4. Analysis of Variance $(\mathrm{p}<0.05)$ between twigs biomass from zone A and zone B during the period studied, "Área de Proteção Ambiental do Rio Pacoti”, Ceará, Brazil.

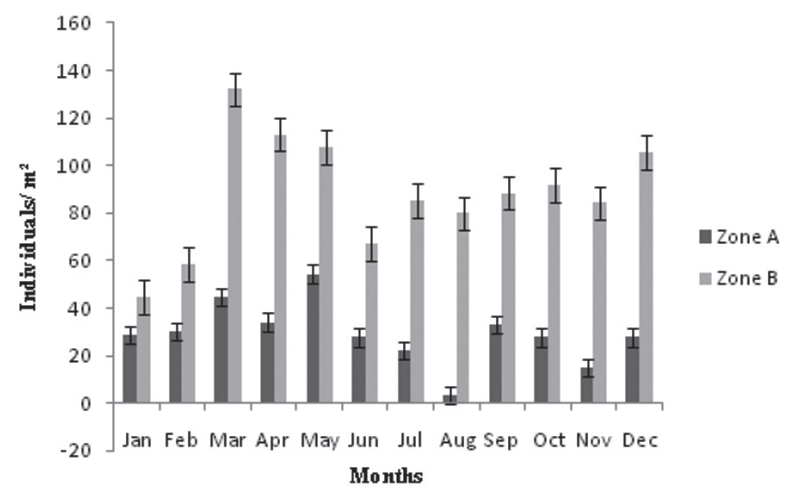

Fig. 5. Population density (individuals $/ \mathrm{m}^{2}$ ) of Melampus coffeus in zone A and zone B during the months of collection at "Área de Proteção Ambiental do Rio Pacoti”, Ceará, Brazil.

The mean shell length was $8.73 \mathrm{~mm}( \pm 3.62)$ in zone $A$ and $13.04 \mathrm{~mm}( \pm 2.62)$ in zone B.

Spearman's correlation test indicated a significant negative correlation between twigs and Melampus coffeus population density (Tab. II) in zone A. For zone B, no significant correlations were found.

\section{DISCUSSION}

The negative strong correlation registered between twig biomass and population density of Melampus coffeus in zone A indicates that smaller snail population density was 
Tab. II. Spearman's correlation results between the number of leaves, different leaf litter fractions, total leaf litter and shell height and population density of $M$. coffeus sampled throughout the studied time, "Área de Proteção Ambiental do Rio Pacoti”, Ceará, Brazil. Values in bold represents significance correlation $(\mathrm{p}<0.05)$.

\begin{tabular}{lcc}
\hline & Shell height & Population density \\
\hline Leaves & 0.028 & 0.151 \\
Number of leaves & 0.252 & 0.148 \\
Reproductive parts & -0.217 & -0.081 \\
Twigs & -0.063 & $\mathbf{- 0 . 7 1 1}$ \\
Miscelaneous & 0.094 & 0.514 \\
Total leaflitter & -0.209 & -0.570 \\
\hline
\end{tabular}

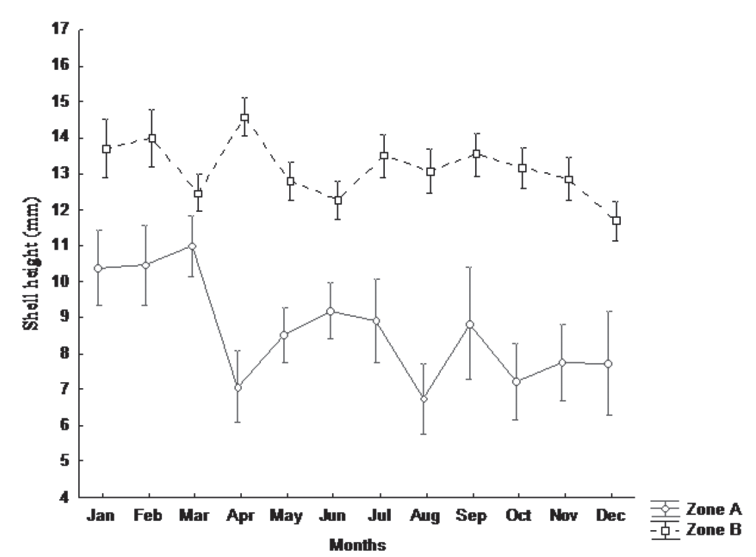

Fig. 6. Analysis of Variance $(\mathrm{p}<0.05)$ between shell height $(\mathrm{mm})$ means of Melampus coffeus samples collected in zones A and B during the period studied, "Área de Proteção Ambiental do Rio Pacoti”, Ceará, Brazil.

recorded where large amounts of twigs occurred. According to BenNer \& Hodson (1985), the Rhizophora mangle wood has, approximately, $80 \%$ of its dry biomass consisting of lignocellulose, while its leaves are consisted of just $50 \%$ of this compound. The same researchers affirmed that only some fungi and bacteria are able to decompose such macromolecular complex, making it almost indigestible for most animals. So, as there is a large amount of lignocellulose in Rhizophora mangle, snails, as the gastropods Melampus coffeus, probably are not attracted by these structures, because they are not important food sources, due to the difficulty to degrade lignocellulose.

Twigs were the most representative litter fraction in both zones. Such representation may be due to its hard decomposition associated to its highest weight, compared to other constituents of plant litter. However, twig biomass was lower in zone B than in zone A. This lower amount of twigs most likely led to the lack of significant correlations between twig biomass and Melampus coffeus population density in zone B.

The greatest accumulation of twigs in zone A was probably due to its topographic characteristics. Zone A was located in a more elevated area, when compared to Pacoti River and zone B, hence, it is possibly less exposed to flooding. In fact, field observations may support such idea, since zone B was always waterlogged, with puddles, and the substrate used to be much muddier than that of zone A. Areas that are more frequently submerged by tidal inundation must have higher rates of litter exportation (Twilley et al., 1986). Thus, litter biomass accumulate less in zone B than in zone A.

Even though no significant correlation was detected, the smaller individuals of Melampus coffeus were recorded in zone A, where larger amounts of twigs were collected. Despite the fact that twigs are probably not an appropriate food source for these snails, such structures may provide a favorable environment for occupation by juveniles, promoting their protection against desiccation and predators. Juveniles tend to be more susceptible to desiccation and the twigs structural arrangement might retain enough humidity to support their survival (TAVARES et al., 2011).

Adults of Melampus coffeus feed on falling leaves observed on the surface of mangrove substrate (PROFFIT et al., 1993; Proffitt \& Delvin, 2005). In the present study, it was expected to find higher population densities of $M$. coffeus in areas with larger leaf biomass or larger number of leaves. Although higher population densities were always found in zone B, throughout the studied months, no statistical differences were detected between leaf litter biomass and number of leaves from both tested zones. Thus, the availability of food sources did not represent the main factor influencing the spatial distribution of $M$. coffeus in the studied area. However, more investigations are needed to understand the feeding behavior of this specie. Maybe, leaves are not their favorite food source and these animals may feed on other tissues, such as microalgae and small vegetal detritus. In addition, it is also necessary to study the potential predators of these animals.

Maia \& Coutinho (2013) suggested that deforestation has a significant influence on $M$. coffeus distribution, both on snail size and population density. According to our results, if leaf litter really provides an important shelter to the juvenile snails, the mangrove forest structure and mangrove production must be a fundamental factor for the maintenance of this species, hence, these gastropods may be used as ecological indicator of mangrove environmental conditions.

Acknowledgements. This article is part of a M.Sc. dissertation conducted in the Programa de Pós-Graduação em Ecologia e Recursos Naturais Renováveis, Universidade Federal do Ceará. We thank the Coordenação de Aperfeiçoamento de Pessoal de Nível Superior (CAPES) for the financial support and the Centro de Estudos Ambientais e Costeiros (CEAC) of the Instituto de Ciências Marinhas, Universidade Federal do Ceará for allowing our entrance in the studied area. We are also thankful to Débora Castelo Branco for reviewing the English writing of this article.

\section{REFERENCES}

Acosta, C. A. \& Butler IV, M. J. 1997. Role of mangrove habitat as a nursery for juvenile spiny lobster, Panulirus argus, in Belize. Marine Freshwater Research 48:721-727.

Andrade, F. \& Ferreira, M. A. 2006. A simple method of measuring beach profiles. Journal of Coastal Research 22:995-999.

Benner, R. \& Hodson, R. E. 1985. Microbial degradation of the leachable and lignocellulosic components of leaves and wood of Rhizophora mangle in a tropical mangrove swamp. Marine Ecology Progress Series 23:221-230. 
CAmilleri, J. C. 1992. Leaf-litter processing by invertebrates in a mangrove forest in Queensland. Marine Biology 114:139-145.

Chapman, M. G.; Michie, K. \& LasiaK, T. 2005. Responses of gastropods to changes in amounts of leaf litter and algae in mangrove forests. Journal of Marine Biology Association 85:1481-1488.

CRowe, T. 1996. Different effects of microhabitat fragmentation on patterns of dispersal of an intertidal gastropod in two habitats. Journal of Experimental Marine Biology and Ecology 206:83-107.

Feir, B. J. \& Toothaker, L. E. 1974. The ANOVA F-test versus the Kruskal-Wallis test: A robustness study. Chicago, Annual meeting of the American educational research association. 38p.

FUNCEME - Fundação Cearense de Meteorologia e Recursos Hídricos. 2010. Posto do Eusébio. Available at $<$ http://www.funceme.br/>. Accessed on October 2010.

Gorayeb, A.; Silva, E. V. \& Meireles, A. J. A. 2005. Impactos ambientais e propostas de manejo sustentável para a planície flúvio - marinha do rio Pacoti - Fortaleza/Ceará. Sociedade \& Natureza 19:143-152.

Kon, K; KuRoKuRA, H \& Tongnunui, P. 2009. Do mangrove root structures function to shelter benthic macrofauna from predators? Journal of Experimental Marine Biology and Ecology 370:1-8.

MaIA, R. C. \& CoutinHo, R. 2013. The influence of mangrove structure on the spatial distribution of Melampus coffeus (Gastropoda: Ellobiidae) in Brazilian stuaries. Panamjas 8(1):21-29.

Maia, R. C. \& TanaKa, M. O. 2007. Avaliação de efeitos de espécies de mangue na distribuição de Melampus coffeus (Gastropoda, Ellobiidae) no Ceará, nordeste do Brasil. Iheringia, Série Zoologia 97:379-382.

McIvor, C.C. \& Sмith, T. J. 1995. Differences in the crab fauna of mangrove areas at a south west Florida and Northeast Australia location: implications for leaf litter processing. Estuaries 18:591-597.

Моок, D. 1986. Absorption efficiencies of the intertidal mangrove dwelling mollusk Melampus coffeus Linné and the rocky intertidal mollusk Acanthopleura granulate Gmelin. Marine Ecology 7:105-113.

Odum, E. W. \& Heald, E. J. 1972. Trophic analysis of an estuarine mangrove community. Bulletin of Marine Science 22:671-738.

Primavera, J. H. 1997. Socioeconomic impacts of shrimp culture. Aquaculture Research 28:815-827.

Proffitt, C. E.; Johns, K. M.; Cochrane, C. B.; Delvin, D. J.; Reynolds, T. A.; Payne, D. L.; Jappesen, S.; Peel, D. W. \& Linden, D. D. 1993. Field and laboratory experiments on the consumption of mangrove leaf litter by the macrodetritivore Melampus coffeus L. (Gastropoda: Pulmonata). Biological Sciences 56:211-222.
Proffit, C. E. \& Delvin, D. J. 2005. Grazing by the intertidal gastropod Melampus coffeus greatly increases mangrove leaf litter degradation rates. Marine Ecology Progress Series 296:209-218.

Rios, E. C. 1994. Seashells of Brazil. 2ed. Rio Grande, Museu Oceanográfico da FURG. 368p.

Rönnbäck, P.; Macia, A.; Almqvist, G.; Schultz, L. \& Troell, M. 2002. Do Penaeid shrimps have a Preference for Mangrove Habitats? Distribution Pattern Analysis on Inhaca Island, Mozambique. Estuarine, Coastal and Shelf Science 55:427-436.

Schaeffer-Novelli, Y. \& Cintrón, G. 1986. Guia para estudo de áreas de manguezal: estrutura, função e flora. São Paulo, Caribbean Ecological Research. 150p.

Semace. 2009. Área de preservação ambiental (APA) do Rio Pacoti. Available at $<$ http://www.semace.ce.gov.br/2010/12/area-deprotecao-ambiental-do-rio-pacoti/>. Accessed on October 2009.

ShimakuRA, S. E. 2006. Interpretação do Coeficiente de Relação. Avaliable at $<$ http://leg.ufpr.br/ silvia/CE003/node74.html $>$. Accessed on March 2015.

Skilleter, G. A. \& Warren, S. 2000. Effects of habitat modification in mangroves on the structure of mollusc and crab assemblages. Journal of Experimental Marine Biology and Ecology 244:107-129.

Stat Soft Inc. 2004. Statistica. Sistema de software para análise de dados. Disponível em: <http://www.statsoft.com.br/pt/index.php>. Acesso em: 01.12.2013.

Suzuki, T.; Nishinira, M. \& Paphavasit, N. 2002. Size structure and distribution of Ovassiminea brevicula (Gastropoda) in a Thai mangrove swamp. Wetlands Ecology and Management 10:265-271.

Tavares, D. S.; Maia, R. C. \& Rocha-Barreira, C. A. 2011. Contribuição do Melampus coffeus (Gastropoda, Ellobidae) na degradação da serapilheira do médio estuário do Rio Pacoti, Ceará, Brasil. Iheringia, Série Zoologia 101(1-2):56-60.

Twilley, W.; Lugo, A. E. \& Patterson-Zuca, C. 1986. Litter production and turnover in basin mangrove forests in southwest Florida. Ecology 67:670-683.

WARNER, G. F. 1969. The occurrence and distribution of crabs in a Jamaican mangrove swamp. Journal of Animal Ecology 38:379-389. 